\title{
PREVALENCE AND CORRELATES OF INSUFFICIENT PHYSICAL ACTIVITY AMONG DIABETIC PATIENTS IN ALMATY, KAZAKHSTAN
}

\author{
${ }^{1}$ M. A. Zhuzenova, ${ }^{1}$ G. P. Kasymova, ${ }^{2}$ N. S. Akhtaeva \\ ${ }^{1}$ Kazakhstan Medical University «KSPH», Almaty, Kazakhstan; ${ }^{2}$ S. D. Asfendiyarov Kazakh National Medical University, \\ Almaty, Kazakhstan
}

Introduction: Physical activity (PA) is an important contributor to health. However, little is known regarding the prevalence of insufficient PA in Kazakhstan.

Aim: To study the prevalence of insufficient PA and associated factors among type 2 diabetic patients in Almaty, Kazakhstan.

Methods: A cross-sectional questionnaire-based study. In total, 480 patients selected using the national diabetes registry. Associations between insufficient PA and age, gender, education, occupation, alcohol consumption, smoking, intake of vegetables and fruits were studied using chi-squared tests and multivariable Poisson regression with robust variance estimation. In addition, the patients were asked about the reasons for not practicing PA as well as about the source of advice on PA. The results are presented as crude and adjusted prevalence ratios (PR) with $95 \%$ confidence intervals (CI).

Results: The overall prevalence of insufficient PA was 60.4 (95\% CI: $56.0 ; 64.7) \%$. Education (PR =0.80, $95 \%$ CI: 0.68; 0.88), employment $(P R=0.74,95 \% C I: 0.64 ; 0.88)$, daily consumption of fruits $(P R=0.78,95 \% C I: 0.67 ; 0.92)$ and vegetables $(P R=0.80,95 \%$ CI: $0.70 ; 0.92)$ were all significantly associated with lower prevalence of insufficient PA in crude analysis. However, after adjustment for other factors, only employment ( $P R=0.72,95 \%$ CI: $0.60 ; 0.86)$ remained significantly associated with the outcome. In total, $61.7 \%$ of the patients received no counseling on PA. The lowest prevalence of insufficient PA (21.6\%) was observed in attenders of commercial sports centers.

Conclusions: High prevalence of insufficient PA combined with poor counseling practices warrant intersectoral cooperation in the development of a strategy to improve PA among type 2 diabetes patients and general population in Kazakhstan.

Key words: physical activity, diabetes, Kazakhstan, Central Asia

\section{НЕДОСТАТОЧНАЯ ФИЗИЧЕСКАЯ АКТИВНОСТЬ У ПАЦИЕНТОВ С САХАРНЫМ ДИАБЕТОМ В ГОРОДЕ АЛМАТЫ (КАЗАХСТАН): РАСПРОСТРАНЕННОСТЬ, СВЯЗАННЫЕ ФАКТОРЫ И БАРЬЕРЫ}

\author{
() 2021 г. ${ }^{1}$ М. А. Жузенова, ${ }^{1}$ Г. П. Касымова, ${ }^{2}$ Н. С. Ахтаева \\ ${ }^{1}$ Казахстанский медицинский университет «ВШ03», г. Алматы; \\ Казахский национальный медицинский университет С. Д. Асфендиярова, г. Алматы, Казахстан
}

\begin{abstract}
Введение: Физическая активность (ФА) является важным фактором, влияющим как на течение диабета 2 типа у пациентов, так и на вероятность его возникновения у здоровых людей. Однако, несмотря на обилие международной литературы по данной теме, исследований в Казахстане по данной теме крайне мало.

Цель: Оценить распространенность и факторы риска недостаточной ФА среди больных диабетом 2 типа в г. Алматы, Казахстан. Методы: 480 больных диабетом 2 типа, отобранных по данным Национального диабетического регистра из всех районов г. Алматы, приняли участие в поперечном исследовании с использованием онлайн-анкетирования. С помощью многомерных моделей Пуассона с робастной оценкой стандартных ошибок оценивали связь между недостаточной ФА и возрастом, полом, образованием, родом занятий, курением, употреблением алкоголя, фруктов и овощей. Дополнительно изучали барьеры для достижения рекомендованного уровня ФА, а также кем подбирались уровни ФА. Результаты представляли в виде нескорректированных и скорректированных отношений распространенности (ОР) с $95 \%$ доверительными интервалами (ДИ).

Результаты: Распространенность недостаточной ФА составила 60.4 (95\% ДИ: 56,0; 64,7) \%. Высшее образование (OP $=0,80,95 \%$ ДИ: 0,$68 ; 0,88)$, наличие постоянной работы $(O P=0,74,95 \%$ ДИ: 0,64; 0,88), ежедневное употребление фруктов $(O P=0,78,95 \%$ ДИ: 0,$67 ; 0,92)$ и овощей $(0 P=0.80,95 \%$ ДИ: 0,70; 0,92) было значимо связано с более низкой распространенностью недостаточной ФА в одномерных моделях. При проведении многомерного моделирования только наличие работы осталось значимо связано с исходом $(O P=0,72,95 \%$ ДИ: 0,60; 0,86). Не получили подбора физической активности 61,7 \% пациентов. Наиболее низкая дола распространенности недостаточной ФА отмечена у пациентов, посещающих платные спортивные центры.

Выводы: Высокая распространенность недостаточной ФА в сочетании с неудовлетворительной практикой назначения ФА пациентам с диабетом 2 типа вызывают необходимость межсекторального сотрудничества для разработки комплексной стратегии увеличения уровня ФА как среди диабетиков, так и среди всего населения в Казахстане.

Ключевые слова: физическая активность, диабет, Казахстан, Центральная Азия
\end{abstract}

For citing:

Zhuzenova M. A., Kasymova G. P., Akhtaeva N. S. Prevalence and Correlates of Insufficient Physical Activity among Diabetic Patients in Almaty, Kazakhstan. Ekologiya cheloveka (Human Ecology). 2021, 10, pp. 44-50.

Библиографическая ссылка:

Жузенова М. А., Касымова Г. П., Ахтаева Н. С. Недостаточная физическая активность у пациентов с сахарным диабетом в городе Алматы (Казахстан): распространенность, связанные факторы и барьеры // Экология человека. 2021. № 10. С. 44-50. 


\section{Introduction}

Type 2 diabetes is a chronic metabolic non-communicable disease representing a significant public health concern with a substantial impact on life expectancy, life quality and health system expenditures worldwide. According to the International Diabetes Federation estimates the global prevalence of diabetes will reach $8.8 \%$ by 2035 [14]. An increase in the burden of diabetes is more pronounced in the developing countries parallel to economic development and westernization and lifestyle [23]. Reliable data on the epidemiology of type 2 diabetes in Kazakhstan is scarce. Even less information is available on the effectiveness of treatment and rehabilitation of diabetic patients in the country. According to The Global Health Observatory the prevalence of type 2 diabetes in Kazakhstan is $13.2 \%$ [29], but it may vary greatly between the urban and rural areas as well as across age- and ethnic groups. The total number of registered cases of type 2 diabetes in Kazakhstan was 326.5 thousand in 2018 representing a substantial burden for the health care system, but the authors acknowledge that the real numbers can be even greater [19]. Ablaikhanova et al have reported a clear North-South gradient in the disease occurrence and expected the total number of people with diabetes in Kazakhstan to reach 1 million by 2030 [4].

Supiyev et al have reported the prevalence of type 2 diabetes in the capital city of Nur-Sultan (Astana at the time of the study) to be $16.3 \%$, but the study was limited to the 5075-year-olds [26]. More importantly, that study revealed poor control of diabetes among the patients. Only $39.7 \%$ of urban patients had controlled fasting blood glucose, but the corresponding proportion among the rural residents was striking $4.9 \%$ [26]. These findings may reflect poor health literacy of the population, limited treatment options or poor compliance to treatment.

Appropriate medication, diet and physical activity are the three pillars for successful management of type 2 diabetes. However, the Cochrane review from 2017 suggested that there was "no clear evidence whether... physical activity alone influences the risk of type 2 diabetes mellitus" [26] Moreover, they concluded that the "data on patient-important outcomes such as mortality, macrovascular- and microvascular diabetic complications are sparse" [15]. However, more recent reviews and meta-analyses have shown physical activity to reduce the risk of diabetes among healthy individuals [8] and to be beneficial for diabetic patients $[6,18,21]$. In a cohort study of more than 3 thousand patients $\mathrm{Hu}$ et al has shown that the mortality among the patients with high physical activity was less than a half of that in the low physical activity group [16]. The Russian national standard of treatment of type 2 diabetes postulates that regular physical activity contributes to reach target levels of blood glucose, reduce weight, abdominal obesity, and insulin resistance, improve blood lipids, and increase cardiac fitness [13].
The recommended level of physical activity includes 30-60 minutes of aerobic physical exercises for per day at least 3 times a week with a total duration of 150 minutes or more [1]. The intensity of physical activity should be individually tailored depending on patient's conditions. These recommendations are also used in Kazakhstan. According to the World Health Organization diabetic profiles, $58.7 \%$ of the general adult population are overweight, $23.5 \%$ are obese and $20.0 \%$ have insufficient physical activity. We identified only one paper from Kazakhstan in international peer reviewed literature on physical activity using internationally validated assessment instruments on healthy subjects, which suggests that the proportions of adults living in Almaty with low- moderate- and high levels of physical activity were $24.3 \%, 39.9 \%$ and $35.8 \%$, respectively [22]. Diabetic patients may have a substantial number of barriers to exercise, knowledge on which may help to improve diabetic care and rehabilitation in the country and to improve the quality of life of the patients. Moreover, the knowledge on the barriers may have implications for the general population. The international evidence as summarized in a recent systematic review and meta-analysis suggests that the adherence to prescribed physical activity varied between $49 \%$ and $100 \%$ with the average of $80 \%$ for diabetic patients based on 9 studies [20]. However, no information on this issue is available from Kazakhstan warranting research on physical activity and barriers to reach recommended levels with the further going aim to improve glycemic control and improve the quality of life of diabetic patients.

The aim of the study was to assess the proportion of diabetic patients reaching the recommended levels of physical activity and associated factors as well as to study the barriers on the way to adhere to these recommendations in a Kazakhstani setting.

\section{Methods}

A questionnaire-based cross-sectional study was performed in the former capital city of Almaty. The total population of the city was 1.9 million in 2020. Presumably all diabetic patients in Kazakhstan are registered in the National Diabetes Registry (NDR). On the $31^{\text {st }}$ of December 2019, the total number of patients living and receiving treatment in Almaty was 40506.

The required sample size for the main research question, namely, the proportion of patients achieving the recommended level of physical activity, was calculated for the precision of $5 \%$ for the finite population equal to the abovementioned number of patients and no a-priory prevalence data on physical activity using WinPEPI software as described elsewhere [2]. To account for dropouts and missing data, the calculated sample size was increased by $25 \%$. Thus, we planned to invite at least 476 patients with verified type 2 diabetes. The patients were recruited at district policlinics in all city districts. The number of patients per district was proportional to the total number of patients in the district 
to ensure geographic representativeness of the sample. Table 1 summarizes the total number of patients and the number of recruited participants across districts in the city of Almaty. The final sample consisted of 480 participants.

Table 1

Estimated minimal required sample size per district for the assessment of the proportion of diabetic patients achieving the recommended level of physical activity in Almaty, Kazakhstan

\begin{tabular}{l|c|c|c}
\hline \multicolumn{1}{c|}{ District } & $\begin{array}{c}\text { Total number } \\
\text { of patients in } \\
\text { the district }\end{array}$ & $\begin{array}{c}\text { Required } \\
\text { number of } \\
\text { participants }\end{array}$ & $\begin{array}{c}\text { Number } \\
\text { of recruited } \\
\text { participants }\end{array}$ \\
\hline Almaly & 6485 & 76 & 76 \\
\hline Alatau & 3421 & 40 & 41 \\
\hline Auezov & 7352 & 86 & 86 \\
\hline Bostandyk & 6847 & 81 & 82 \\
\hline Zhetisu & 4422 & 52 & 52 \\
\hline Medeu & 4525 & 53 & 53 \\
\hline Nauryzbay & 1619 & 19 & 20 \\
\hline Turksib & 5835 & 69 & 70 \\
\hline Total & 40506 & 476 & 480 \\
\hline
\end{tabular}

All study participants answered an anonymous 61 item internet-based questionnaire. Those who had difficulties filling out an online form were invited to a district endocrinologist to fill out a paper-based form. For this study only the following information was used: age, gender, education, marital status, occupation, smoking, alcohol consumption, fruits- and vegetables intake, whether the participants reached the recommended level of physical activity, places for practicing physical activity, types of physical activity, reasons for not exercising, types of diabetic school they attended and information on who prescribed individual level of physical activity.

The main outcome variable for the purpose of this study was dichotomized into whether the individuals reach the recommended level of physical activity (30 or more minutes every day or at least 3 times a week in total accounting for at least 150 minutes) or not. All intermediate categories used in other studies were merged with the "no" category. Education was dichotomized into secondary or lower including vocational and higher. By marital status all patients were grouped into married and single. The latter group also included widowed, divorced and co-habiting. By occupation the participants were dichotomized into employed including individual entrepreneurs and military servants and unemployed including students, pensioners, and those on disability pensions. Consumption of fruits \& berries and vegetables was dichotomized into daily and less often. By smoking status, the participants were divided into daily smokers irrespectively of the number of cigarettes smoked per day and non-smokers. By alcohol consumption they were dichotomized into self-reported abstainers and alcohol drinkers. This dichotomization was used due to small numbers in sub-groups of those who reported drinking alcohol. Multiple choice questions on other aspects of physical activity were categorized as specified in Table 2 .
The prevalence of the sufficient physical activity was calculated using Wilson's $95 \%$ confidence interval (CI). Associations between the probability to reach the recommended level of physical activity and all independent variables were studied using Pearson's chi-squared tests. Yate's correction for continuity and Fischer's exact tests were applied where appropriate. Independent associations between the studied factors and the odds of achieving the recommended level of physical activity were studied using multivariable Poisson regression with robust standard errors estimations. Poisson regression is superior to traditional logistic regression for binomial outcomes in cross-sectional studies when the prevalence of the outcome is expected to exceed $10 \%$. Crude and adjusted prevalence ratios (PR) with $95 \%$ CI were estimated. All calculations were performed using Stata software (Stata Corp, TX, USA) [3].

The study was approved by the local ethics committee at the Kazakhstan Medical University «KSPH» in Almaty, Kazakhstan.

\section{Results}

The prevalence of insufficient PA among the patients in the city was 60.4 (95 \% CI: $56.0 ; 64.7) \%$. The recommended level was reached by only $39.6 \%$ (95\% CI: $35.3 ; 44.0) \%$.

In crude analysis, individuals with higher education and those who were employed had lower prevalence of IPA. Other socio-economic characteristics were not associated with the studied outcome. Daily or consumption of vegetables as well as fruits \& berries were less likely to have IPA. Alcohol and smoking were not associated with the prevalence of IPA.

After introduction of all the variables into one multivariable Poisson model, the association between IPA and education decreased to non-significant values. At the same time, the association between IPA and occupation remained significant. Patients who were in paid job we $39 \%$ more likely to reach the recommended level of physical activity than the reference group. The associations between daily consumption of consumption of vegetables were considerably reduced and became non-significant. At the same time, the results for the association between IPA and fruits \& berries consumption in multivariable analysis were inconclusive - those who reported eating fruits and berries at least daily were $21 \%$ more likely to reach the recommended level of physical activity $(p=0.050)$. The results on the associations between IPA and socio-demographic variables are presented in Table 2 while Table 3 summarizes the results on the associations between IPA and lifestyle factors.

Altogether, 374 participants reported the type of physical activity they practiced. Among them, the most common activities included walking (48.1\%), gymnastics $(20.1 \%)$ and swimming $(17.9 \%)$. We found significant associations between the prevalence of IPA and the type of physical activity $(\mathrm{P}<0.001$, Table 4$)$. The prevalence of IPA varied between $9.1 \%$ among 
Table 2

Proportions of type 2 diabetic patients with insufficient physical activity (IPA) across socio-demographic characteristics in Almaty, Kazakhstan

\begin{tabular}{|c|c|c|c|c|c|c|c|c|}
\hline Characteristic & $\mathrm{N}$ & $\%$ & IPA, \% & $\mathrm{P}$ & Crude PR & $95 \% \mathrm{CI}$ & Adjusted PR & $95 \%$ CI \\
\hline Age, years & & & & 0.872 & & & & \\
\hline $18-55$ & 205 & 42.7 & 60.0 & & 1.00 & Reference & 1.00 & Reference \\
\hline $56+$ & 275 & 57.3 & 60.7 & & 1.01 & $-0.87 ; 1.17$ & 0.92 & $0.79 ; 1.07$ \\
\hline Gender & & & & 0.175 & & & & \\
\hline Male & 200 & 41.7 & 64.0 & & 1.11 & $0.96 ; 1.28$ & 1.13 & $0.96 ; 1.31$ \\
\hline Female & 280 & 58.3 & 57.9 & & 1.00 & Reference & 1.00 & Reference \\
\hline Marital status & & & & 0.260 & & & & \\
\hline Married & 278 & 57.9 & 58.3 & & 0.92 & $0.80 ; 1.06$ & 0.98 & $0.85 ; 1.12$ \\
\hline Other & 202 & 42.1 & 63.4 & & 1.00 & Reference & 1.00 & Reference \\
\hline Education & & & & 0.009 & & & & \\
\hline Higher & 161 & 33.5 & 52.5 & & 0.80 & $0.68 ; 0.96$ & 0.86 & $0.73 ; 1.02$ \\
\hline Other & 319 & 69.5 & 64.6 & & 1.00 & Reference & 1.00 & Reference \\
\hline Occupation & & & & $<0.001$ & & & & \\
\hline Employed & 202 & 42.1 & 50.5 & & 0.74 & $0.64 ; 0.88$ & 0.72 & $0.60 ; 0.86$ \\
\hline Out of work & 278 & 57.9 & 67.8 & & 1.00 & Reference & 1.00 & Reference \\
\hline
\end{tabular}

PR - Prevalence ratio calculated using Poisson regression with robust standard error estimation

$\mathrm{CI}$ - Confidence intervals

Table 3

Proportions of type 2 diabetic patients with insufficient physical activity (IPA) across lifestyle characteristics in Almaty, Kazakhstan

\begin{tabular}{l|c|c|c|c|c|c|c|c}
\hline Consumption of: & $\mathrm{N}$ & $\%$ & IPA, $\%$ & $\mathrm{P}$ & Crude PR & $95 \%$ CI & Adjusted PR & $95 \%$ CI \\
\hline Fruits \& berries & & & & 0.003 & & & & \\
\hline Daily & 186 & 38.3 & 55.2 & & $\mathbf{0 . 7 8}$ & $\mathbf{0 . 6 7 ; 0 . 9 2}$ & 0.83 & $0.70 ; 1.00$ \\
\hline Less often & 296 & 61.7 & 68.9 & & 1.00 & Reference & 1.00 & Reference \\
\hline Vegetables & & & & 0.002 & & & & \\
\hline Daily & 297 & 61.9 & 51.6 & & $\mathbf{0 . 8 0}$ & $\mathbf{0 . 7 0 ; 0 . 9 2}$ & 0.93 & $0.80 ; 1.10$ \\
\hline Less often & 183 & 38.1 & 65.9 & & 1.00 & Reference & 1.00 & Reference \\
\hline Alcohol & & & & 0.403 & & & & \\
\hline Yes & 193 & 59.8 & 62.7 & & 1.06 & $0.92 ; 1.23$ & 1.09 & $0.93 ; 1.27$ \\
\hline No & 287 & 40.2 & 58.9 & & 1.00 & Reference & 1.00 & Reference \\
\hline Daily smoking & & & & 0.234 & & & & \\
\hline Yes & 154 & 32.1 & 64.1 & & 1.10 & $0.95 ; 1.27$ & 1.06 & $0.89 ; 1.25$ \\
\hline No & 326 & 67.9 & 58.6 & & 1.00 & Reference & 1.00 & Reference \\
\hline
\end{tabular}

PR - Prevalence ratio calculated using Poisson regression with robust standard error estimation

CI - Confidence intervals

those who practiced Pilates and $84.6 \%$ among the patients who reported dancing as their main activity.

Table 4

Associations between the type of physical activity and the proportion of individuals with insufficient physical activity (IPA) in Almaty, Kazakhstan

\begin{tabular}{l|c|c|c}
\hline Type of activity & $\%$ & $\%$ IPA & P \\
\hline & & & $<0.001$ \\
\hline Walking & 48.1 & 54.4 & \\
\hline Gymnastics & 20.1 & 58.7 & \\
\hline Swimming & 17.9 & 20.9 & \\
\hline Yoga & 7.5 & 64.3 & \\
\hline Dancing & 2.9 & 84.6 & \\
\hline Pilates & 0.5 & 9.1 & \\
\hline
\end{tabular}

At the same time, 173 responders answered the question on the reason for not practicing regular physical activity. The most common answer though was "no particular reason" (43.3\%). No motivation was mentioned in additional $7.8 \%$ of the patients. Among the remaining reasons the most popular were "Cannot afford going to a sports center" (18.6\%), "Heart problems" (17.6\%), "Poor glycemic control" (7.2\%) and "Orthostatic hypotension" (5.2\%). Thus, medical reasons accounted for less than one third of all reported reasons for not reaching sufficient physical activity.

In total, $49.8 \%$ of the study participants reported that they received no individual counseling on physical activity. As many as $11.9 \%$ of the sample reported that they made their own decision on the duration, intensity, and frequency of physical activity. However, $11.0 \%$, $7.3 \%$ and $2.5 \%$ of the patients said that their physical activity was tailored by an endocrinologist, a cardiologist, and a neurologist, respectively. In $6.5 \%$ of the cases recommendations on physical activity were given by general practitioners and in $6 \%$ at schools of diabetes.

The proportion of patients with IPA varied between 
$33.3 \%$ if the physical activity was recommended by a neurologist and $64.5 \%$ among the patients who did not receive physical activity counseling (Table 5). Since the results did not reach the level of statistical significance, we could not perform multivariable modelling to study independent associations between this variable adjusted for the patients' socio-economic and lifestyle characteristics.

Associations between the proportion of individuals with insufficient physical activity (IPA) and the source of advice on physical activity in Almaty, Kazakhstan

\begin{tabular}{l|c|c|c}
\hline \multicolumn{1}{c|}{ Source } & $\%$ & $\%$ IPA & P \\
\hline & & & 0.074 \\
\hline No counseling & 61.7 & 64.5 & \\
\hline Cardiologist & 7.3 & 60.0 & \\
\hline Neurologist & 2.5 & 33.3 & \\
\hline Endocrinologist & 11.0 & 58.5 & \\
\hline Endocrinology nurse & 2.7 & 61.5 & \\
\hline General practitioner & 6.5 & 61.3 & \\
\hline Diabetes school & 6.0 & 41.4 & \\
\hline Instructor at the sports center & 2.3 & 36.4 & \\
\hline
\end{tabular}

As for the location where the patients do exercise, this question was answered by 366 patients while the rest reported that they did not exercise at all. Most of them exercised at home. The proportion of those who did not reach the recommended level of physical activity varied between $21.6 \%$ among the users of commercial sports centers and $67.8 \%$ among those who exercised at home (Table 6).

Associations between the proportion of individuals with insufficient physical activity (IPA) and place of exercise

\begin{tabular}{l|c|c|c}
\hline \multicolumn{1}{c|}{ Place } & $\%$ & $\%$ IPA & P \\
\hline & & & $<0.001$ \\
\hline Home & 33.1 & 68.7 & \\
\hline Adjacent areas & 28.7 & 56.2 & \\
\hline Commercial sports center & 24.0 & 21.6 & \\
\hline Free outdoor facilities & 14.2 & 51.2 & \\
\hline
\end{tabular}

\section{Discussion}

This is among the first studies in Kazakhstan providing an insight into the issue of PA in diabetic patients, its correlates, and reasons for not attaining the recommended level of PA. The results suggest that almost two thirds of the patients do not reach the recommended level of PA. Moreover, the only factor significantly associated with the outcomes was occupation suggesting that a major part of PA is related to work and/or travel to and from work. The situation is further complicated by the fact that more than $60 \%$ of the patients reported that they received no counseling on PA and the sources of advice on PA varied considerably. At the same time, the proportion of patients with sufficient PA was the highest among those who attended commercial sports centers and the second highest among those who received counseling from an instructor there. Pilates and swimming we the types of activities with the greatest proportion of responders who reached the level of physical activity. These findings provide important insights into the problem of insufficient PA in diabetic patients in Almaty and may have implications for general population of the city. However, these findings should be interpreted cautiously considering potential limitations of the study.

The validity of the findings depends on the validity of the data. It has been shown that responders in Kazakhstan are prone to social desirability bias [10]. If this is true for this study, then our findings on the prevalence of insufficient PA are likely to be underestimated. However, the degree of underestimation is unlikely to be substantial given the prevalence of smoking in the sample which is close to the estimates in other studies on general adult population of Almaty [28]. The proportion of individuals abstaining from alcohol was also only a little higher than in general population of the same city [28] suggesting that the validity of our estimates including PA is likely to be valid. Therefore, inadequate consumption of fruits and vegetables is a source of concern. Fruits [30] and particularly vegetables [27] have been repeatedly shown to have not only preventive effect on developing type 2 diabetes, but also contribute to better glycemic control. At the same time, insufficient vegetable intake despite recommendations has been noted in many countries [9]. Our findings are generally in the same direction showing that diabetic patients who are more physically active are more likely to consume more fruits and vegetables [12], although our findings had borderline significance for fruits and berries and did not reach the level of significance for vegetables. Interestingly, we have not found any associations between PA and socio-demographic variables except occupation. This may reflect little information in general available for patients regarding PA.

The results presented in this paper can be used as a basis for recognition of inadequate PA promotion among the patients with type 2 diabetes in Almaty. Substantial heterogeneity of the sources of counseling on PA combined with the fact that almost two thirds of the responders received no counseling on PA at all is worrisome. Only $11 \%$ of the responders received guidance on PA based on their physical and medical conditions from their endocrinologists who are in the best position to prescribe PA with certain intensity, frequency, and duration. Diabetes schools should support the patients to reach the levels of PA prescribed by the endocrinologists.

Although this study shows that the greatest proportion of patients who reach the recommended levels of PA attend commercial sports centers this option is suitable for the minor part of the population due to low affordability by the majority. Therefore, free options available for everybody like walking or low-cost options like yoga should be preferred. Regular walking effectively increases physical strength, and energy consumption behavioral aspects, and decreased $\mathrm{HbAlc}$, and triglyceride levels in elderly people with type II diabetes [25]. 
At the same time, a four-month exercise programs at moderate intensity of either Nordic walking or exercise on prescription had no effect on $\mathrm{HbAlc}$ in patients with type 2 diabetes [13].

There is a growing body of literature presenting yoga as an alternative to aerobic exercises in diabetic patients to prevent physical and mental complications [7]. It may reduce stress and anxiety which in turn are associated with unhealthy eating and elevated blood pressure and thus have a beneficial health effect in diabetic patients [24]. However, systematic reviews suggests that the studies are too heterogeneous, the evidence is inconclusive but deserving further research [8, 11]. Moreover, systematic reviews of exercise and physical activity interventions do not consistently make clear whether to consider yoga as an exercise [8]. Given an increased interest in yoga in Kazakhstan in the recent years, research on its effects on medical conditions and quality of life of diabetic patients could be a promising area for research.

It should be emphasized that real medical problems were mentioned as barriers to reach the recommended level of PA by less then a third of the responders while the majority reported no particular reason and no motivation as the main reason for not exercising. This may partly reflect poor health literacy regarding beneficial effects of PA on the course of type 2 diabetes and poor quality of counseling by medical personnel. At the same time, it may also mirror the level of PA and attitude towards it in general population in Almaty. Therefore, we are convinced that there is an urgent need to develop strategies to assist diabetic patients in adopting and maintaining an active lifestyle. Intersectoral cooperation has been shown to be effective to promote PA in Korean Healthy Cities [17] and this successful practice could be transferred to Kazakhstan after some cultural adjustment. Public health strategies to increase PA in the general population is likely to be more beneficial than strategies aimed at risk groups or patients. Heterogeneity of PA counseling practices observed in this study justifies the need for unification of practices of prescribing PA to type 2 diabetic patients.

In conclusion, we observed very high prevalence of insufficient PA in the largest city of Kazakhstan. Only occupation which could be a proxy for occupational physical activity was associated with the outcome. This may also reflect low levels of health literacy in general population warranting interdisciplinary approach to tackle the inactivity among Kazakhstani adults in general and diabetic patients in particular. The barriers and PA patterns identified in this study should be considered in development of the strategy aimed at enhancing PA among type 2 diabetic patients and general population in Kazakhstan.

\section{Authors' contribution}

All authors equally contributed to study design, data acquisition, data analysis and writing. The final version of the paper was approved by all three authors.
Zhuzenova Makpal Adilovna - ORCID 0000-0002-7888-6644 Kasymova Gulnara Pazylbekovna - ORCID 0000-00019425-405X

Akhtaeva Nazgul Smailkhanovna - ORCID 0000-00020835-9814

\section{References}

1. Дедов И. И., Шестакова М. В., Майоров А. Ю., Викулова О. К., Галстян Г. Р., Қураева Т. Л., Петеркова В. А., Смирнова О. М., Старостина Е. Г., Суркова Е. В., Сухарева О. Ю., Токмакова А. Ю., Шамхалова М. Ш., Ярек-Мартынова И. Р., Артемова Е. В., Бешлиева Д. Д., Бондаренко О. Н., Волеводз Н. Н., Григорян О. Р., Гомова И. С., Джемилова 3. Н., Есаян Р. М., Ибрагимова Л. И., Калашников В. Ю., Кононенко И. В., Лаптев Д. Н., Липатов Д. В., Мотовилин О. Г., Никонова Т. В., Роживанов Р. В., Шестакова Е. А. Алгоритмы специализированной медицинской помощи больным сахарным диабетом / под ред. И.И. Дедова, М. В. Шестаковой, А. Ю. Майорова; 9-й выпуск // Сахарный диабет. 2019. T. 22, № 1S1. C. $1-144$.

Dedov I. I., Shestakova M. V., Mayorov A. Yu., Vikulova O. K., Galstyan G. R., Kuraeva T. L., Peterkova V. A., Smirnova O. M., Starostina E. G., Surkova E. V., Sukhareva O. Yu., Tokmakova A. Yu., Shamkhalova M. S., JarekMartynova I. R., Artemova E. V., Beshlieva D. D., Bondarenko O. N., Volevodz N. N., Grigoryan O. R., Gomova I. S., Dzhemilova Z. N., Esayan R. M., Ibragimova L. I., Kalashnikov V. Yu., Kononenko I. V., Laptev D. N., Lipatov D. V., Motovilin O. G., Nikonova T. V., Rozhivanov R. V., Shestakova E. A. Standards of specialized diabetes care. Edited by Dedov I. I., Shestakova M. V., Mayorov A. Yu., 9th edition. Diabetes Mellitus. 2019, 22 (1S1), pp. 1-144. [In Russian]

2. Гржибовский А. М., Горбатова М. А., Наркевич А. Н., Виноградов К. А. Необходимый объем выборки для сравнения долей в двух независимых группах // Морская медицина. 2020. Т. 6, № 3. С. 76-83.

Grjibovski A. M., Gorbatova M. A., Narkevich A. N., Vinogradov K. A. Required sample size for comparing proportions in two independent samples. Morskaya Meditsyna [Marine medicine]. 2020, 6 (3), pp. 76-83. [In Russian]

3. Унгуряну T. Н., Гржибовский А. М. Программное обеспечение для статистической обработки данных STATA: введение // Экология человека. 2014. № 1. С. 60-63.

Unguryanu T. N., Grjibovski A. M. Introduction to Stata - software for statistical data analysis. Ekologiya cheloveka (Human Ecology). 2014, 1, pp. 60-63. [In Russian]

4. Ablaikhanova NT, Yessenbekova AY, Tazhiyeva A, Yessimsiitova ZB, Saidakhmetova AK, Malibayeva AE, Sanbaeva BJ, Molsadykkyzy M. Issues of Type 2 Diabetes Disease Effective Treatment in Kazakhstan. Journal of Pharmacy and Nutrition Sciences. 2020, 10, pp. 116-122.

5. Aune D, Norat T, Leitzmann M, Tonstad S, Vatten LJ. Physical activity and the risk of type 2 diabetes: a systematic review and dose-response meta-analysis. Eur J Epidemiol. 2015, 30 (7), pp. 529-42.

6. Balducci S, Sacchetti M, Haxhi J, Orlando G, D’Errico V, Fallucca S, Menini S, Pugliese G. Physical exercise as therapy for type 2 diabetes mellitus. Diabetes Metab Res Rev. 2014, 30 Suppl 1, pp. 13-23.

7. Bali P, Kaur N, Tiwari A, Bammidi S, Podder V, Devi C, Kumar S, Sivapuram MS, Ghani A, Modgil S, Malik N, Anand A. Effectiveness of Yoga as the Public Health Intervention Module in the Management of Diabetes and Diabetes Associated Dementia in South East Asia: A Narrative Review. Neuroepidemiology. 2020, 54 (4), pp. 287-303. 
8. Brinsley J, Girard D, Smout M, Davison K. Is yoga considered exercise within systematic reviews of exercise interventions? A scoping review. Complement Ther Med. 2021, 56, p. 102618.

9. Coleone JD, Bellei EA, Roman MK, Kirsten VR, De Marchi ACB. Dietary Intake and Health Status of Elderly Patients with Type 2 Diabetes Mellitus: Cross-sectional Study Using a Mobile App in Primary Care. JMIR Form Res. 2021 Aug 27, 5 (8), e27454.

10. Craig BJ, Engstrom MC. Public Health and Social Desirability in Kazakhstan: Methodological Considerations. Cent Asian J Glob Health. 2016, 4 (2), p. 191.

11. Cui J, Yan JH, Yan LM, Pan L, Le JJ, Guo YZ. Effects of yoga in adults with type 2 diabetes mellitus: A meta-analysis. J Diabetes Investig. 2017, 8 (2), pp. 201-209.

12. Ferretto LR, Bellei EA, Biduski D, Bin LCP, Moro MM, Cervi CR, De Marchi ACB. A Physical Activity Recommender System for Patients with Arterial Hypertension. IEEE Access. 2020, 8, pp. 61656-61664.

13. Gram B, Christensen R, Christiansen C, Gram J. Effects of nordic walking and exercise in type 2 diabetes mellitus: a randomized controlled trial. Clin J Sport Med. 2010, 20 (5), pp. 355-61.

14. Guariguata L, Whiting DR, Hambleton I, Beagley J, Linnenkamp U, Shaw JE. Global estimates of diabetes prevalence for 2013 and projections for 2035. Diabetes Res Clin Pract. 2014, 103 (2), pp. 137-149.

15. Hemmingsen B, Gimenez-Perez G, Mauricio D, Roqué I Figuls M, Metzendorf MI, Richter B. Diet, physical activity or both for prevention or delay of type 2 diabetes mellitus and its associated complications in people at increased risk of developing type 2 diabetes mellitus. Cochrane Database Syst Rev. 2017, 12 (12), CD003054.

16. Hu G, Jousilahti P, Barengo NC, Qiao Q, Lakka TA, Tuomilehto J. Physical activity, cardiovascular risk factors, and mortality among Finnish adults with diabetes. Diabetes Care. 2005, 28 (4), pp. 799-805.

17. Kang E. Intersectoral collaboration for physical activity in Korean Healthy Cities. Health Promot Int. 2016, 31 (3), pp. 551-61.

18. Kirwan JP, Sacks J, Nieuwoudt S. The essential role of exercise in the management of type 2 diabetes. Cleve Clin J Med. 2017, 84 (7 Suppl 1), S15-S21.

19. Mukasheva S, Saparkhojayev N, Akanov Z, Algazieva A. The prevalence of diabetes in the Republic of Kazakhstan based on regression analysis methods. International Journal of Health and Medical Sciences. 2019, 5, pp. 8-16.

20. Nam S, Dobrosielski DA, Stewart KJ. Predictors of exercise intervention dropout in sedentary individuals with type 2 diabetes. J Cardiopulm Rehabil Prev. 2012, 32 (6), pp. $370-8$.

21. Nery C, Moraes SRA, Novaes KA, Bezerra MA, Silveira PVC, Lemos A. Effectiveness of resistance exercise compared to aerobic exercise without insulin therapy in patients with type 2 diabetes mellitus: a meta-analysis. Braz J Phys Ther. 2017, 21 (6), pp. 400-415.

22. Nugmanova D, Feshchenko Y, Iashyna L, Polianska M, Malynovska K, Stafeyeva I, Makarova J, Vasylyev A. Association between body mass index and patient-reported-outcome questionnaire scores (CAT ${ }^{\mathrm{TM}}, \mathrm{ACT}^{\mathrm{TM}}, \mathrm{mMRC}$ dyspnoea scale, IPAQ) in Ukraine, Kazakhstan and Azerbaijan: results of the CORE study. BMC Pulm Med. 2021, 21 (1), p. 192.

23. Onyango EM, Onyango BM. The rise of noncommunicable diseases in Kenya: an examination of the time trends and contribution of the changes in diet and physical inactivity. J Epidemiol Glob Health. 2018, 8, pp. 1-7.

24. Smith C, Hancock H, Blake-Mortimer J, Eckert K. A randomised comparative trial of yoga and relaxation to reduce stress and anxiety. Complement Ther Med. 2007 Jun, 15 (2), pp. 77-83.

25. Sung K, Bae S. Effects of a regular walking exercise program on behavioral and biochemical aspects in elderly people with type II diabetes. Nurs Health Sci. 2012, 14 (4), pp. 438-45.

26. Supiyev A, Kossumov A, Kassenova A, Nurgozhin T, Zhumadilov Z, Peasey A, Bobak M. Diabetes prevalence, awareness and treatment and their correlates in older persons in urban and rural population in the Astana region, Kazakhstan. Diabetes Res Clin Pract. 2016, 112, pp. 6-12.

27. Villegas R, Shu XO, Gao YT, Yang G, Elasy T, Li H, Zheng W. Vegetable but not fruit consumption reduces the risk of type 2 diabetes in Chinese women. J Nutr. 2008, 138 (3), pp. 574-80.

28. Vinnikov D, Raushanova A, Romanova Z, Tulekov Z. Health-related quality of life in a general population sample in Kazakhstan and its sociodemographic and occupational determinants. Health Qual Life Outcomes. 2021, 19 (1), p. 199.

29. WHO (2013) Global health observatory - data repository [Online]. http://apps.who.int/ghodata/files/84/ghodata.html.

30. Wu C, Liu P, Yuan Z. Fruit and vegetable intake is inversely associated with type 2 diabetes in Chinese women: results from the China Health and Nutrition Survey. Int $J$ Food Sci Nutr. 2021 Mar, 72 (2), pp. 208-218.

\section{Contact details:}

Makpal Zhuzenova - MD, PhD student at the Kazakhstan Medical University «KSPH», 19a Utepova St., Almaty 050060, Kazakhstan

E-mail: mzhuzenova@inbox.ru 